\title{
UNDER INVOICING IN THE RESIDENTIAL REAL ESTATE MARKET IN PAKISTAN
}

\author{
Abdul WAHID (1) 1, ${ }^{*}$, Edmund H. MANTELL (D) ${ }^{2}$, Muhammad Zubair MUMTAZ (iD ${ }^{3}$ \\ ${ }^{1}$ NUML School of Business, National University of Modern Languages (NUML), Islamabad, Pakistan \\ ${ }^{2}$ Lubin School of Business, Pace University, 1 Pace Plaza, NY 10038 New York, USA \\ ${ }^{3}$ School of Social Sciences and Humanities (S3H), National University of Science and Technology (NUST), \\ Islamabad, Pakistan
}

Received 01 May 2020; accepted 28 December 2020

\begin{abstract}
In this paper the meaning of "under invoicing in a real estate market" signifies that the market value of real property exceeds its record value appearing in government documentation. The purpose of this study is to identify the level of under invoicing and determine the factors that affect the under invoicing in real estate markets in Pakistan. We apply OLS and Extreme Bounds Analysis techniques to test our propositions. The statistical sample consists of 338 real estate contracts. We find that under invoicing is determined by a multiplicity of factor. These include: the capital gains tax rate, the measurable amount of corruption in the economy, the risk-free rate, a buyer's profession, the reputation of the local housing authority, and the degree of disequilibria in regional real estate markets. Our findings are consistent with four distinct hypotheses: (a) tax evasion hypothesis, (b) widening gap hypothesis, (c) a corruption hypothesis and (d) a signaling hypothesis. The evidence suggests that higher rates of taxation and a larger statistical incidence of corruption in markets tend to be associated with a greater probability of under-invoicing. The findings of the study have practical implications for those investors who are interested in real estate markets of emerging and developing economies.
\end{abstract}

Keywords: under-invoicing, real estate market, tax evasion, black money, widening gap, extreme bounds analysis.

\section{Introduction}

Housing markets in developing countries have been found to be relatively dynamic because of volatile returns and extraordinarily high liquidity. Over the past two decades, several countries experienced high returns and high liquidity in real estate relative to capital markets (Bian et al., 2019; Brounen et al., 2019; Liu et al., 2019). In general, one can observe a rapid escalation in the prices of some kinds of real estate over time. In a dichotomized market for real estate, the prices of similar properties vary from each other because of administrative inefficiencies reflecting haphazard record keeping by local governmental bodies (Andrew \& Meen, 2003; Waltl, 2019). Pervasive differences between prices of comparable properties are another factor contributing to differences in invoicing. The difference between the market value of a property and its recorded value has been called under invoicing (Patnaik et al., 2012). In this paper we address the observable factors systematically associated with under invoicing.
The explanatory hypotheses we address include: (1) systematic tax evasion, (2) the persistence of a widening gap between assessed value and market value, (3) endemic corruption, (4) a signaling hypothesis, (5) the reputation of the local housing authority and (6) market sentiment. These hypotheses have been discussed in the literature of international trade, export and import businesses (e.g. Beja, 2008; Patnaik et al., 2012). The different theories attempt to explain the factors that cause under invoicing and many are supported by empirical evidence in import and export businesses.

An unresolved question is why under invoicing is a common occurrence in the real estate market in Pakistan. There are several theoretical as well as practical reasons as to why the incidence of under invoicing is of interest. Sandmo (2005) found a general trend among traders to report the lower value of assets or property on invoices relative to its market value. He suggested that this tendency was a manifestation of tax evasion strategy. In this study,

${ }^{*}$ Corresponding author. E-mail: abwahid.fms@gmail.com

Copyright $\odot 2021$ The Author(s). Published by Vilnius Gediminas Technical University

This is an Open Access article distributed under the terms of the Creative Commons Attribution License (https://creativecommons.org/licenses/by/4.0/), which permits unrestricted use, distribution, and reproduction in any medium, provided the original author and source are credited. 
we test the role of the tax evasion hypothesis to explain under invoicing in a real estate market. This hypothesis allows us to develop a theory to explain how varying tax rates may induce under in voicing in real estate markets.

A second testable theory analyses the explanatory power of the huge gap between government's prescribed rates of assessment and the market value of properties. This paper explores the causal link between the widening gap hypothesis and the incidence of under invoicing. Previous literature (Ahmed Qureshi \& Mahmood, 2016; Beja, 2008; Patnaik et al., 2012) explored the theory that higher levels of corruption (sometimes referred to as "black money") in an economy tends to be associated with increases in the incidence of under invoicing. In this study, we explore the nexus between the statistical incidence of under invoicing and black money.

Some researchers have theorized that the effect of positive market sentiments is to push up the general level of prices in the market. For example, recent studies (Hui \& Wang, 2014; Wang \& Hui, 2017), found that market sentiments and investors' sentiments were significantly positively correlated with the variation of housing prices. In this paper, we analyze two issues: (a) We examine how the variability of market sentiments influences the transaction prices of real properties and (b) We address the question of whether the variations in those sentiments are systematically related to under invoicing in real estate. Infrastructure development has been shown to affect the dynamic equilibria of the residential housing market (Hromada, 2015). In this study we explore the question of whether sector development in the real estate market is systematically associated under invoicing in that market.

The reputation of the local housing authority is considered an important determinant of the value of real properties in Pakistan. Previous studies found that a housing authority's prestige is an important factor in pricing of properties (Abidin et al., 2012; Hutchison \& Disberry, 2015; Pugh, 2001). This paper includes among the explanatory variables the reputation of the local housing authority. The effect of market signaling on the level of prices is its impact, if any, on the incidence of under invoicing in the real estate market. The analyses carried out in this paper are conducted in stages. In the first stage we identify possible theoretical explanations of under-invoicing. In the second stage we identify the possible factors that affect pricing level using Extreme Bound Analysis (EBA) (Leamer, 1983, 1985). In addition, we conduct sensitivity analysis by identifying the robust predictors that associated with underinvoicing.

\section{Literature review}

\subsection{Theoretical foundations}

According to Global Financial Integrity (GFI), "mis-invoicing" consists of fraudulently manipulating the value of assets and/or property on an invoice as to misrepresent its market value when documentation of a transaction is submitted to a tax authority. The differences between the market value of a property and its recorded value has been called under invoicing (Patnaik et al., 2012). Previously published studies reported under-invoicing in different countries e.g. Pakistan (Ahmed Qureshi \& Mahmood, 2016), China (Beja, 2008), and other developing countries (Cassara, 2016; Musliu et al., 2015; Woodward \& Tan, 2015). It is generally thought that real estate markets of developing countries, especially in Pakistan, experience pervasive under-invoicing. The pervasiveness of under invoicing in real estate markets in developing countries raises numerous questions regarding the economic (and other) explanations for under-invoicing in those markets. The explanatory hypotheses proposed include: (1) systematic tax evasion, (2) persistence of a widening gap between assessed value and market value, (3) endemic corruption, (4) a signaling hypothesis, (5) the reputation of housing authority and (6) market sentiment.

Sandmo (2005) found a general trend among traders to report lower values of assets or property on invoices relative to their transaction values. He suggested that this tendency was a manifestation of tax evasion strategy. During contract negotiations, both parties agree to report a specious small transaction price for the purchased property on the sales deed in order to evade the real estate transaction tax. Earlier studies used various proxies relating to tax evasion. These included: covering Capital Gains Tax (CGT), Capital Value Tax (CVT), Stamp Duty and Withholding Tax or Advance Tax in real estate (Blackburn et al., 2012). Tax evasion theory associates the incidence of tax evasion with the informal/undocumented economy (Sandmo, 2005). An economy in which real estate sales transactions are not documented scrupulously provides fertile ground, almost an invitation, for systematic underinvoicing. For example, the undocumented economy in Pakistan, where under-invoicing in real estate transactions is common, accounts for between forty to fifty percent of the entire economy (Gulzar et al., 2010). Sharply progressive real estate tax rates provide a clear incentive for the parties to engage in the practice of under invoicing, thereby mitigating and evading tax liability.

A different (but not inconsistent) explanatory hypothesis relates to the changes in the difference between the assessments of assets and property established by government authorities and market transaction prices of those assets. We refer to that difference as the "widening gap". This gap produces undocumented cash flows circulating in the real estate market, which provides the means as well as the incentive for under invoicing in that market. In a developing economy such as Pakistan, the market value of assets and properties are not determined by tax departments and municipal authorities (Low et al., 2016; Rymarzak \& Siemińska, 2012). In Pakistan, most transactions in the real estate are based on so-called "DC rates", established by government authorities. However, the actual transaction prices are recorded as per the market value. As a result of this discrepancy, unrecorded cash flows pervade 
the real estate market. The divergence between the DC rate and the market values can be used as a proxy variable to explain under-invoicing.

According to the Federal Board of Revenue Pakistan (2019), existing prices of real property in the Islamabad range from 15.000 rupees to 93.000 rupees per $\mathrm{yd}^{2}\left(0.836 \mathrm{~m}^{2}\right)$. In Rawalpindi the range is from $5.000 \mathrm{ru}-$ pees to 73.000 rupees per $\mathrm{yd}^{2}\left(0.836 \mathrm{~m}^{2}\right)$. A question we will explore is whether common characteristics in such diverse housing markets are valued differently by real estate investors in those two cities.

Previously published research focused on the endemic corruption hypothesis as a factor responsible for under invoicing in the real estate market. The percentage increase in corruption has been found to be directly associated with the level of under invoicing in the economy (Anson et al., 2015; Patnaik et al., 2012). Moreover, the relationship is manifested as a positive correlation (Patnaik et al., 2012). Statistical data indicating changes in the level and magnitude of corruption appear in reports of different agencies such as Transparency's Corruption Perceptions Index (CPI), appearing in the World Economic Forum's assessment. We also use Transparency International and Amnesty International Report as proxy for the level of corruption and black money in the market.

Other studies documented the role of real estate market factors in the under invoicing of assets and properties (Ling et al., 2019; Rymarzak \& Siemińska, 2012). The signaling hypothesis is one of the most debated theories; it suggests that variation of asset prices and properties are related to different market signals and market dynamics. Studies of initial public offerings in stock markets identified the signaling hypothesis as factor responsible for underpricing such as (Alim \& Ramakrishnan, 2017; Cheng \& McMillan, 2015). In this study the signaling hypothesis is considered a possible explanatory factor for under invoicing.

The risk-free return on investment may also help to explain the incidence of under invoicing. The economic theory of causality can be explained this way: If the riskfree rate of return increases, ceteris paribus, the rate of savings will likewise increase. To the extent that savings increases, again ceteris paribus, one would expect to observe an increase in business investment activity, including activity in the real estate market as well as increase in business activities in the aggregate economy (Ascherl \& Schaefers, 2018; Brobert, 2016). Infrastructure and sector development and increasing residential construction both affect the dynamic equilibrium of the residential housing market (Hromada, 2015). That kind of development tone would expect to cause increases in housing prices, which may be systematically related to under invoicing in the market.

Market sentiments and investor sentiments are also included in signaling theory. Previous studies carried out in capital and financial markets suggested that market sentiment plays a significant role in causing price volatility
(Badru \& Ahmad-Zaluki, 2018; Rathnayake et al., 2019). One can bifurcate the sentiment variable: i.e., an optimistic sentiment of future market movements will tend to push up the general level of prices (called a "hot market") and pessimistic view of the future market will tend to depress the general level of prices (a "cold market"). The reputation of the housing authority is considered an important determinant of under invoicing of real properties. Previous studies related to financial markets (Arora \& Singh, 2019; Chen et al., 2013; Jeribi, 2015), especially initial public offerings (IPOs), considered the underwriter's prestige as important factor in pricing of IPOs.

Generally, it is thought that a small difference between market value of properties and value appearing on invoices is an indicator of the prestige of the housing authority. Statistical evidence supporting the theory should show a negative correlation between the magnitude and he incidence of under invoicing and the prestige of the local housing authority. The employment status of buyer and seller may be significantly associated with transaction prices as well as under invoicing in the Pakistani real estate markets. Most employed persons are tax payers in Pakistan because their taxes are deducted by the employer. In order to get tax rebates, tax payers file tax returns every year. As a result, they have tax incentives to report recorded prices lower than transaction prices on their properties to get the benefits of tax rebates.

This paper incorporates the theories outlined above to test the fundamental question: What are significant explanatory variables systematically related to under invoicing in the real estate market of Pakistan.

\subsection{The real estate market and its temporal changes in Pakistan}

According to the 2017 Census of Pakistan, the population of Pakistan was more than 207 million. It has been growing by an average $2.40 \%$ per annum. Pakistan has multicultural and multilingual ethnic societies. It hosts one of the largest Afghan refugee populations in the world. The age distribution of Pakistan's population is relatively young; more than $60 \%$ of the population is between the ages of 4 years and 30 years and that proportion has been steadily increasing.

Lack of basic facilities in villages and the industrialization in rural areas have led to rapid urbanization and the emergence of megacities (Pakistan Bureau of Statistics, 2017a, 2017b). As a consequence of those trends, Pakistan has become the second-most urbanized nation in South Asia, with urban residents constituting about $35 \%$ of its population as shown Table 1.

As per the 2017 Census of Pakistan and the Pakistan Bureau of Statistics, there are two megacities i.e., Karachi and Lahore with 15 million and 11 million population, respectively. The same sources record 99 cities having a population of 100,000 or more. Of those 99 cities, 58 cities are located in country's most populous province Punjab, 22 cities in Sindh, 11 cities in Khyber Pakhtunkhwa, five 
Table 1. Growth in demand for residential properties due to urbanization and growth in population (source: The World Bank, 2019b)

\begin{tabular}{|c|c|c|c|c|c|}
\hline Year & Population & $\begin{array}{c}\text { \% Change in } \\
\text { population }\end{array}$ & $\begin{array}{c}\text { Urban population } \\
\text { (\% population) }\end{array}$ & $\begin{array}{c}\text { Rural population } \\
\text { (\% population) }\end{array}$ & Population density \\
\hline 2000 & $142,343,578$ & $2.83 \%$ & 32.982 & 67.018 & 184.651 \\
\hline 2005 & $160,304,008$ & $2.41 \%$ & 33.997 & 66.018 & 207.949 \\
\hline 2010 & $179,424,641$ & $2.28 \%$ & 36.234 & 65.003 & 232.753 \\
\hline 2015 & $199,426,964$ & $2.14 \%$ & 36.026 & 63.093 & 275.289 \\
\hline 2016 & $203,631,353$ & $2.11 \%$ & 35.819 & 63.334 & 269.687 \\
\hline 2017 & $207,906,209$ & $2.10 \%$ & 35.613 & 63.558 & 264.149 \\
\hline 2018 & $212,228,286$ & $2.08 \%$ & 35.408 & 63.766 & 258.7 \\
\hline 2019 & $216,565,318$ & $2.04 \%$ & 35.202 & 63.974 & 260.55 \\
\hline 2020 & $220,892,340$ & $2.00 \%$ & 34.997 & 63.203 & 262.412 \\
\hline
\end{tabular}

Table 2. Market prices of residential property in Pakistan (source: Zameen, 2019)

\begin{tabular}{|c|c|c|c|c|c|c|}
\hline Year & $\begin{array}{c}\text { Price per } \mathrm{m}^{2} \text { in } \\
\text { Islamabad }\end{array}$ & $\begin{array}{c}\text { Price per } \mathrm{m}^{2} \text { in } \\
\text { Rawalpindi }\end{array}$ & $\begin{array}{c}\text { Price per } \mathrm{m}^{2} \text { in } \\
\text { Faisalabad }\end{array}$ & $\begin{array}{c}\text { Price per } \mathrm{m}^{2} \text { in } \\
\text { Karachi }\end{array}$ & $\begin{array}{c}\text { Price per } \mathrm{m}^{2} \text { in } \\
\text { Lahore }\end{array}$ & $\begin{array}{c}\text { Price per } \mathrm{m}^{2} \text { in } \\
\text { Multan }\end{array}$ \\
\hline 2011 & 21743 & 23885 & 16609 & 47738 & 23595 & 46554 \\
\hline 2012 & 24456 & 28105 & 17793 & 62409 & 28772 & 47964 \\
\hline 2013 & 36005 & 38330 & 18514 & 87198 & 40214 & 53960 \\
\hline 2014 & 38782 & 41194 & 18751 & 96821 & 45467 & 57286 \\
\hline 2015 & 39191 & 41194 & 22561 & 113527 & 50407 & 61796 \\
\hline 2016 & 42787 & 41312 & 23864 & 127660 & 55897 & 62388 \\
\hline 2017 & 40645 & 42485 & 22873 & 139802 & 56683 & 65369 \\
\hline 2018 & 42453 & 36737 & 26070 & 136282 & 59923 & 67113 \\
\hline 2019 & 45951 & 48890 & 26802 & 130469 & 61613 & 73840 \\
\hline 2020 & 48534 & 51258 & 31743 & 133569 & 64788 & 79179 \\
\hline
\end{tabular}

cities in Balochistan, two cities in Azad Kashmir and one city in Islamabad Capital Territory (Pakistan Bureau of Statistics, 2017b).

Increases in population and growing urbanization have led to rapid increases in residential real estate in urban centers. The growth is observable in Karachi, Lahore, Rawalpindi, Faisalabad, Islamabad, and Multan. The most prestigious housing societies and authorities are the Defense Housing Authority (DHA), Bahria town, Capital Smart City, Blue World City and Multi-Gardens (Hasan, 2010). The market values of properties in the large cities are increasing rapidly as shown in Table 2. A government policy intended to promote real estate activity imposed a decrease in interest rates on mortgage loans in 2012. As a consequence, the real estate market of Pakistan has become Asia's largest real estate market; it is experiencing an average annual growth rate of approximately $9 \%$. Nationwide house prices, in nominal terms, rose by $5.05 \%$ to PKR 117058 (US\$ 829) per $\mathrm{m}^{2}$ as also shown in Table 2.

\subsection{Market competitiveness and transaction transparency in Pakistan}

Pakistan spends an annual amount of approximately $\$ 5.2$ billion in its housing market. That constitutes about $2 \%$ of its GDP. According to the State Bank of Pakistan (SBP), published industry surveys estimate that the residential real estate industry has a current value of about $\$ 700$ billion. Real estate and construction, together, account for approximately two percent of Pakistan's total GDP (Choudhry et al., 2017).

A unique aspect of Pakistan's real estate market is that the industry recorded its maximum volatility during the period from 2010 to 2020, as shown in Table 3. Elsewhere in the world (excluding the 2005 sub-prime mortgage crisis), the real estate industry tends to show a steady annual growth rate in the neighborhood of five to eight percent. In Pakistan, however, monthly growth rates of more than $10 \%$ are routinely recorded.

Pakistani domestic markets show evidence of increasing corruption. Pakistan also ranks low in Global Competitiveness Index in 2020 and constantly decreasing since 2017, as shown in Table 4. Since 2018, Pakistan has been ranked the world's lowest in ease of doing business. Many of the industries in Pakistan have been become technologically obsolete and the development of new businesses is trending downward.

The economic factors described above have not had an adverse effect on Pakistan's real estate market. That market has been steadily increasing for ten years. According to a World Bank estimate, the average size of a country's real 
Table 3. Industrial sector disaggregation in the GDP of Pakistan (source: State Bank of Pakistan [SBP], n.d. All mounts are in PKRs (million))

\begin{tabular}{|c|c|c|c|c|c|c|}
\hline Year & $\begin{array}{c}\text { Wholesale and } \\
\text { retail trade }\end{array}$ & $\begin{array}{c}\text { Transport, } \\
\text { storage and } \\
\text { communication }\end{array}$ & $\begin{array}{c}\text { Finance and } \\
\text { insurance }\end{array}$ & $\begin{array}{c}\text { Housing and } \\
\text { construction }\end{array}$ & $\begin{array}{c}\text { Government } \\
\text { services }\end{array}$ & $\begin{array}{c}\text { Other private } \\
\text { services }\end{array}$ \\
\hline 2010 & 1718014 & 1198896 & 274674 & 614460 & 569191 & 832901 \\
\hline 2011 & 1746511 & 1254126 & 279171 & 639003 & 632130 & 886204 \\
\hline 2012 & 1808124 & 1304697 & 302392 & 664542 & 703717 & 932776 \\
\hline 2013 & 1894410 & 1355570 & 315428 & 691093 & 723823 & 990839 \\
\hline 2014 & 1943612 & 1424255 & 335448 & 718674 & 758746 & 1050844 \\
\hline 2015 & 2035509 & 1493830 & 356981 & 747343 & 832505 & 1122032 \\
\hline 2016 & 2187751 & 1557639 & 396669 & 777140 & 882015 & 1213253 \\
\hline 2017 & 2331415 & 1587297 & 426012 & 808172 & 986125 & 1320737 \\
\hline 2018 & 2357094 & 1660857 & 447286 & 840494 & 1037147 & 1396958 \\
\hline 2019 & 2276458 & 1542461 & 450820 & 874283 & 1077842 & 1472202 \\
\hline
\end{tabular}

Table 4. Transparency and competitiveness in Pakistan (source: (a) Corruption Perceptions Rank and Corruption Perceptions Index from Transparency International, n.d.; (b) Global Competitiveness Rank and Global Competitiveness Index from World Economic Forum, 2019; (c) Ease of Doing Business from the World Bank, 2019a)

\begin{tabular}{|c|c|c|c|c|c|}
\hline Year & $\begin{array}{c}\text { Corruption } \\
\text { Perceptions Rank }\end{array}$ & $\begin{array}{c}\text { Corruption } \\
\text { Perceptions Index }\end{array}$ & $\begin{array}{c}\text { Global } \\
\text { Competitiveness } \\
\text { Rank }\end{array}$ & $\begin{array}{c}\text { Global } \\
\text { Competitiveness } \\
\text { Index }\end{array}$ & $\begin{array}{c}\text { Ease of Doing } \\
\text { Business }\end{array}$ \\
\hline 2010 & 143 & 23 & 101 & 3.58 & 96 \\
\hline 2011 & 134 & 25 & 123 & 3.48 & 105 \\
\hline 2012 & 139 & 27 & 118 & 3.57 & 106 \\
\hline 2013 & 127 & 28 & 124 & 3.51 & 110 \\
\hline 2014 & 126 & 29 & 133 & 3.41 & 136 \\
\hline 2015 & 117 & 30 & 129 & 3.41 & 148 \\
\hline 2016 & 116 & 32 & 126 & 3.45 & 144 \\
\hline 2017 & 117 & 32 & 106 & 49.71 & 147 \\
\hline 2018 & 117 & 33 & 107 & 51.08 & 136 \\
\hline 2019 & 120 & 32 & 110 & 51.36 & 108 \\
\hline
\end{tabular}

estate assets constitutes between 60 and $70 \%$ of the country's total wealth; if these estimates are applied to Pakistan, the estimated size of the real estate sector would be $\$ 300$ to $\$ 400$ billion (Tufail \& Batool, 2013). The transactions in the real estate market have been carried out by an increasing number of uneducated agents and dealers who do not have the necessary IT and finance related skills to serve their clientele. The statistical incidence of fraud is significant. At present, the market has contracted because of restrictions on non-filers and the imposition of larger taxes on real estate transactions.

The combination of mis-management and extremely liquid real estate markets in Pakistan provide incentives as well as opportunities for under invoicing As a consequence, under invoicing has become a common occurrence in every real property market in Pakistan and the volume of trade mis-invoicing has exceed US $\$ 92.7$ billion during last two decades (Ahmed Qureshi \& Mahmood, 2016). It is reported that transactions in real estate markets have been recorded at 70 to 80 percent lower value than actual market values in Pakistan (Haque, 2015). In consequence, Pakistan has been declared as low indexed country at 73 ranks out of 100 ranks with 3.88 points in Global Real Estate Transparency Index, 2020 (JLL and LaSalle, 2020).

\section{Methodology}

\subsection{Data and sample}

The sample consisted of 338 executed contracts during the period 2010-2018 in real estate market of Islamabad and Rawalpindi. The sources include property dealers, housing authorities, and other real property recording systems situated in Islamabad and Rawalpindi. In order to match the value of property stated on invoices and the transaction market value of the property, we use sale agreement of the property and market value from property dealers and housing authorities working in those specific areas. They were verified through various open access sources such Zameen.com which is widely used by investor to find the value of real estate properties. 
The data related to taxes have been collected from the different tax files of the Federal Board of Revenue. The statistical data on the net volume of corruption is based on the Transparency's Corruption Perceptions Index (CPI), World Economic Forum's assessment, Transparency International and Amnesty International Report issued. Changes in the magnitude of corruption are measured by the quarterly percentage changes in net volume of corruption in Pakistan. Statistical data about the risk-free rate of return has been transcribed from reports of the State Bank of Pakistan. For the dummy variable defined as "buyer's employment status", we extracted data from the sales contracts between the parties.

\subsection{Econometric equations}

To determine the statistical incidence of under invoicing in real estate market, we use the following definition of under-invoicing:

Under-invoicing $=\left(\frac{(\text { Mkt Price }- \text { Invoice Price })}{\text { Mkt Price }}\right) \times 100$.

Under invoicing is defined as the percentage difference between market value (measured by the transaction price) and the legally documented price of any property recorded by the housing authority. To examine the factors that are systematically related to under invoicing of property, we develop the following model:

Under_invoicing $=\partial_{i}+\gamma_{1}\left(C V T_{i}\right)+\gamma_{2}\left(\right.$ StampDuty $\left._{i}\right)+$ $\gamma_{3}\left(\right.$ Corruption $\left._{i}\right)+\gamma_{4}\left(\right.$ WHT $\left._{i}\right)+\gamma_{5}\left(C G T_{i}\right)+\gamma_{6}\left(R R F_{i}\right)+$ $\gamma_{7}\left(\right.$ Buyer'semployment status $\left._{i}\right)+\gamma_{8}\left(\right.$ Rep. $\left.S_{i}\right)+$ $\gamma_{9}\left(\right.$ Sec.Dev $\left._{i}\right)+\gamma_{10}\left(\right.$ Transfer Fee $\left._{i}\right)+\gamma_{11}\left(\right.$ Widening Gap $\left._{i}\right)+$ $\gamma_{12}\left(M k t\right.$ Sent $\left._{i}\right)+u$.

CVT is a capital value tax which is a percentage levied at total invoiced value of property. Stamp Duty is the percentage of tax paid on legal documentation of assets or properties. Corruption is measured through quarterly percentage change in net volume of corruption in Pakistan. WHT is withholding tax which is to be paid at the time of property deal by buyer and seller of property. CGT is capital gain tax which is paid by seller when seller makes profits on selling property. $R R F$ is return on risk free investment, if it is higher than prices of properties will decrease. One would expect the frequency of under invoicing to decrease. Buyer's employment status is defined as a dummy variable: if the buyer is employed it is assigned a numerical value of 1 , otherwise, 0 . Rep. HS is reputation of housing society. It is a dummy variable: a high reputation is assigned a value of 1 and zero otherwise. We calculate reputation housing societies by following formula: Society 's Portion $_{i, j}=\frac{T_{R} M_{j}}{\sum_{i=0}^{i=n} T R M V_{i}}$. This study considers the portion of each society in the total business done during the sample period in real estate. $T R M_{i, j}=$ total market share of society $j$ in Islamabad and $\sum_{i=0}^{i=n} T R M V_{i}=$ total real estate market volume in Islamabad. We also calculate the median for the participation of all societies as: $\operatorname{Median}_{j}=\operatorname{Median}\left(T R M_{j}\right)$. If society has a value above the median, it is assigned as 1 (i.e. high reputation society), and 0 otherwise. Sec. Dev is number of development projects and facilities available in specific sector or area. Transfer Fee is the amount which is paid at the time of transfer of assets or property. Widening Gap is difference between rates defined by local government as official rates of properties and market prices of properties in specific area or sector. $M k t$ Sent is market sentiment during the time of sale and purchase of specific property and is characterized as 1 for hot and 0 for cold. If the trading magnitude of trading of property is higher than an average volume is assigned as 1 or otherwise, 0 . The symbol $u$ represents a stationary random variable distributed as $N(0,1)$.

\subsection{Econometric methods}

According to Cooley and LeRoy (1981) economic theory does not indicate which of the variables are robust and which should be kept constant while employing any statistical technique or model. In order to address this difficulty, Leamer $(1983,1985)$ developed the Extreme Bound Analysis (EBA). Levine and Renelt (1992) applied that technique. Various parallel models have been developed and used, but the reliability of these models has been called into question. The EBA technique is a reliable method; it can be applied to test the sensitivity of statistical inferences to specification changes. It also reduces the uncertainty associated with model fitness and reliability (Leamer, 1985).

In this study, we examine the robust predictors that influence under invoicing in the real estate market. To determine robust predictors, Moosa and Cardak (2006) defined the following regression:

$$
\begin{aligned}
& \text { Undinv }_{i t}=\beta_{0}+\sum_{i p=1}^{n} \beta_{c} X_{i p i}+\mu_{i} \\
& \text { Undinv }_{i t}=\beta_{0}+\sum_{i p=1}^{n} \delta_{c} X_{i p i}+\beta Q_{i}+\sum_{i p=1}^{m} \delta_{c} z_{i p i}+\mu_{i} .
\end{aligned}
$$

We estimate the coefficient of variable of interest " $Q$ ". The coefficient of that variable is an indicator of sensitivity and robustness. The methodology of the EBA requires many regressions to estimate the value of the coefficient of independent variable. The same variables (s) $X$ are included in every set of regressions. The variable of interest $\mathrm{Q}$ and the set of variables $Z$ are chosen from a predetermined pool.

To get a more precise specification of the model and improve robustness of variables, we use LASSO regression which is widely used to select both variables and measure the accuracy of model. The acronym LASSO signifies Least Absolute Shrinkage and Selection Operator. LASSO regression is a type of liner regression that uses Shrinkage. Shrinkage is where data values are shrunk towards 
a central point, like the mean. The LASSO procedure encourages simple, sparse models, i.e., models with fewer estimable parameters. This kind of econometric application is well-suited for models showing high levels of multicollinearity. The technique was first introduced by (Santosa \& Symes, 1986) and used by (Tibshirani, 1996). The LASSO estimator is the OLS estimator with an L1 penalty term:

$$
\text { Undinv }_{i t}=\frac{1}{2 m} \sum_{i=1}^{m}\left(y_{i}-\beta_{0}+\sum_{j=1}^{p} x_{i} \beta_{j}\right)^{2}+\lambda \sum_{j=1}^{p}\left|\beta_{j}\right| \text {. }
$$

The nature of L1 regularization penalty causes some coefficients to shrink to zero. Here the tuning factor $\lambda$ controls the strength of the penalty. If $\lambda=0$, coefficients are considered as simple linear regression. If $\lambda=\infty$, all coefficients are zero. The range $0<\lambda<\infty$, the coefficients are estimated to assume values between 0 and those generated by a simple linear regression. When $\lambda$ is between the extremes, we are balancing the two ideas. The Lasso regression can perform variable selection in the linear model. As the value of $\lambda$ increases, more coefficients will be set to value zero, meaning that fewer variables are selected for inclusion in the specification. Among the nonzero coefficients, additional shrinkage is manifested.

\section{Result and discussion}

\subsection{The incidence of under invoicing and black money}

The percentage increase in corruption has been found to be directly associated with the level of under invoicing in the Pakistani economy. Moreover, the relationship is manifested as a positively correlation. To examine its effect, this paper relies on the level of corruption reported in Transparency's Corruption Perceptions Index (CPI), appearing in the World Economic Forum's assessment, Transparency International and Amnesty International Report. The statistical data appearing in that Report is used as proxy for the level of corruption and black money in the market. We divide our sample into four quartiles, corresponding to the change in corruption. The paper's findings are displayed on Table 5. The entries appearing on Table 5 are evidence of the positive systematic relationship between the index of corruption and the magnitude of under invoicing depicts that real estate market is under-invoiced property. When the annual change in black money was at the upper extreme i.e., more than $16 \%$ from previous year, the data show that transactions in the real estate market are under-invoiced on average by $39.4 \%(p<0.05)$. Likewise, corruption increases by $8 \%$ in economy, under invoicing decreases to almost $15.51 \%$ which is significant at $99 \%$ confidence $(p<0.05)$. There is significant difference in all four quartiles $(F$ value $=95.54, p<0.05)$. The data strongly support the hypothesis that the level of under invoicing increases as the level of the corruption index increases. This finding is consistent with similar findings in the papers by (Cassara, 2016; Patnaik et al., 2012).

\subsection{Under-invoicing and taxes}

Previous studies suggested that taxes imposed on transactions were positively correlated with the level of under invoicing (Ahmed Qureshi \& Mahmood, 2016; Sandmo, 2005). These studies argued that, generally, sellers underinvoiced their assets to avoid the high level of taxation. This study examines the impact of overall taxes on level of under invoicing in real estate market. Table 6 below displays statistics showing the relationship between the incidence of under invoicing in the real estate market and tax rates imposed on transactions in the real estate market

Table 5. Association between increases in corruption and the incidence of under invoicing (source: author's calculation)

\begin{tabular}{|c|c|c|c|c|}
\hline Corruption & $N$ & Mean & Std. Deviation & Difference between groups (ANOVA) \\
\hline$<=8 \%$ increase in economy & 101 & $15.515^{\star *}$ & 3.276 & \multirow[t]{4}{*}{$F$ value $=95.545^{\star *}$} \\
\hline$>8 \%$ and $<11 \%$ increase in economy & 73 & $27.945^{\star *}$ & 15.305 & \\
\hline$>11 \%$ and $<16 \%$ increase in economy & 83 & $39.446^{* *}$ & 11.418 & \\
\hline$>16 \%$ increase in economy & 81 & $38.481^{\star *}$ & 12.131 & \\
\hline
\end{tabular}

Note: This table exhibits percentage in corruption from previous year and level of under invoicing of sample of 338 contracts of real estate. To test the significance, $t$-statistics is used. ${ }^{*} p<0.05 ;{ }^{* *} p<0.01$ represent significance level at the 1 , and $5 \%$ respectively.

Table 6. Association between the aggregate tax rate and the incidence of under-invoicing (source: author's calculation)

\begin{tabular}{|l|l|c|c|c|}
\hline \multicolumn{1}{|c|}{ Overall volume of tax } & $N$ & Mean & Std. Deviation & Difference between groups (ANOVA) \\
\hline$<=9 \%$ increase in tax & 90 & $29.322^{* *}$ & 14.272 & \multirow{2}{*}{$F$ value $=0.387$} \\
\hline$>9 \%$ and $<11 \%$ increase in tax & 86 & $31.000^{* *}$ & 16.237 & \\
\cline { 1 - 3 }$>11 \%$ and $<13.75 \%$ increase in tax & 77 & $28.597^{* *}$ & 14.362 & \\
\cline { 1 - 3 }$>13.75 \%$ increase in tax & 85 & $29.306^{* *}$ & 14.880 & \\
\hline
\end{tabular}

Note: This table exhibits the association between the levied tax and the incidence of under invoicing in a sample of 338 real estate contracts. The aggregate tax liability consists of the Capital Gains Tax, the Capital Value Tax and the Stamp Duty and Withholding Tax. To test the significance, $t$-statistics levels are symbolized by ${ }^{*} p<0.05 ;{ }^{* *} p<0.01$ represent significance level at the 1 , and $5 \%$ respectively. 
of Pakistan. The data on Table 6 show that when tax rates were at the higher end of the range, i.e., more than $11 \%$, transactions in the real estate market are under-invoiced an average of $31 \%(p<0.05)$. At the other extreme, when the real estate taxis $9 \%$, the incidence of under invoicing is about $29 \%(p<0.05)$. There is no significant difference among the four quartiles $(F$ value $=0.387, p>0.05)$. This finding suggests that the rate of taxation has not significant power to explain variation in under-invoicing.

\subsection{Under-invoicing and rate of return on risk free investments}

It is generally presumed that as the risk-free rate of return increases, ceteris paribus, the rate of savings will likewise increase. To the extent that savings increases, again ceteris paribus, one would expect to observe an increase in business investment activity, including activity in the real estate market as well as increase in business activities of overall economy (Ascherl \& Schaefers, 2018; Brobert, 2016). The increase in real estate transactions will tend over time to cause an increase in the prices of real property. Those transaction price increases may be associated with an increase in under-invoicing. This study analyzes the systematic relationship between the risk-free rates of return and the incidence of under-invoicing.

The sample is partitioned into four sub-samples, based on the magnitude of the risk-free rate of return. Subsample (a) the risk-free rate of return is less than or equal to $8 \%$, (b) the risk-free rate of return is more than $8 \%$ and less than or equal to $9 \%$, (c) the risk-free rate of return is more than $9 \%$ and less than or equal to $11 \%$, and (d) the risk-free rate of return is more than $11 \%$. The statistical findings are displayed on Table 7.
Table 7 reveals positive relationship between the riskfree rate of return and the statistical incidence of underinvoicing. For example, at the highest risk-free rate of return, (more than 11\%), the statistical incidence of under invoicing is largest $(38.57 \%, p<0.05)$. There is a significant difference among all four quartiles $(F$ value $=35.70$, $p<0.05)$. This finding suggests that the incidence of under invoicing tends to increase with increases in the risk-free rate of return.

\subsection{Under-invoicing and widening gap}

It is also generally observed that there is significant difference between "deputy commissioner (DC) rates" and market prices of the properties in the real estate market. Since DC rates are lower relative to the market value of $1 \mathrm{yd}^{2}\left(0.836 \mathrm{~m}^{2}\right)$ in different housing authorities, most of the transactions in the real estate are based on DC rates. However, the actual transaction prices are recorded as per the market value. As a result of this discrepancy, unrecorded cash flows pervade the real estate market.

In order to analyze the interplay between the widening gap and the incidence of under invoicing in the real estate market, we partition the data in our sample into four subsamples, defined by the size of the gap: (a) a gap less than or equal to 10824.5 PKRs, (b) a gap more than 10824.5 and less than 18479 PKRs, (c) a gap more than 18479 and less than 27417.75 PKRs and (d) a gap exceeding 27417.75 PKRs.

The statistical evidence displayed on Table 8 shows that there is a significant positive correlation between the size of the Gap and the statistical incidence of underinvoicing. There are significant differences among all four quartiles $(F$ value $=114.58, p<0.05)$. This statistical finding supports the widening gap hypothesis. It appears that

Table 7. Association between the rate of return on risk free investments and the incidence of under-invoicing (source: author's calculation)

\begin{tabular}{|l|c|c|c|c|}
\hline \multicolumn{1}{|c|}{ Rate of return on risk free investment } & $N$ & Mean & Std. Deviation & Difference between groups (ANOVA) \\
\hline$<=8 \%$ increase in economy & 132 & $21.091^{\star *}$ & 12.366 & \multirow{2}{*}{$F$ value $=35.70^{\star *}$} \\
\hline$>8 \%$ and $<9 \%$ increase in economy & 41 & $28.878^{\star *}$ & 14.887 & \\
\cline { 1 - 3 }$>9 \%$ and $<11 \%$ increase in economy & 82 & $34.488^{* *}$ & 14.014 & \\
\cline { 1 - 4 }$>11 \%$ increase in economy & 83 & $38.578^{* *}$ & 12.117 & \\
\hline
\end{tabular}

Note: Table 3 displays the systematic relationship between the of return on risk free investments and the statistical incidence of under invoicing in a sample of sample of 338 real estate contracts. To test the significance, the $t$-statistic is applied: ${ }^{*} p<0.05 ;{ }^{* *} p<0.01$ represent significance level at the 1 , and $5 \%$ respectively.

Table 8. Association between the widening gap and incidence of under invoicing (source: author's calculation)

\begin{tabular}{|l|c|c|c|c|}
\hline \multicolumn{1}{|c|}{ Widening gap } & $N$ & Mean & Std. Deviation & $\begin{array}{c}\text { Difference between } \\
\text { groups (ANOVA) }\end{array}$ \\
\hline$<=10824.5$ PKRs difference in market price and DC rates & 105 & $15.482^{* *}$ & 3.243 & $F$ value $=114.58^{\star *}$ \\
\hline$>10824.5$ and $<18479$ PKRs difference in market price and DC rates & 64 & $23.238^{* *}$ & 12.090 \\
\hline$>18479$ and $<27417.75$ PKRs difference in market price and DC rates & 94 & $40.500^{* *}$ & 12.262 \\
\hline$>27417.75$ PKRs difference in market price and DC rates & 75 & $39.153^{* *}$ & 11.702 & \\
\hline
\end{tabular}

Note: To test the significance, $t$-statistics is used. ${ }^{\star} p<0.05 ;{ }^{*} p<0.01$ represent significance level at the 1 , and $5 \%$ respectively. 
magnitude of under invoicing increases with increase with the magnitude of the gap.

\subsection{Under invoicing and reputation of housing authority}

The reputation of the housing authority is considered an important determinant of under invoicing of real estate properties in Pakistan. It is thought that a small difference between market value of properties and value appearing on invoices is an indicator of the prestige of the housing authority. In this study, we define dichotomize the sample data to represent two classes of the prestige of the housing authority: high prestige and low prestige as measured in IPOs pricing performance (Arora \& Singh, 2019). The dichotomized sample will help to explain how the prestige of the housing authority can affect the under invoicing. The literature of IPOs suggests a methodology for classifying the reputation of underwriters. We test the effect of the reputation of the housing authority on the incidence of under invoicing in real estate market. In order to carry out the test, we defined the reputation of a local housing authority in Pakistan on the basis of the market share a specific authority regulates. If a real estate governmental institution regulates a market share above the median of overall market share of real estate market, it is assigned as 1 (i.e., high reputation society), and 0 otherwise (Brounen et al., 2019; Wahid et al., 2019).

Table 9 displays statistical evidence suggesting that a "Higher Reputation" of a local housing authority is significantly associated with a smaller statistical incidence of under-invoicing. This finding suggests that the reputation of the housing authority affects the level of under invoicing in real estate market. It supports the signaling hypothesis that a higher market share of a specific housing authority can be construed as a signal that its recorded real estate values are reasonably accurate indicators of market values. That accuracy is a manifestation of the transparency of the recording procedure of that specific authority. That transparency is important to investors and other stakeholders.

\subsection{Under-invoicing and buyer's employment status}

According to Newberry and Collins (2017), employment status is significantly related to the decision of whether to sell or purchase assets. The authors inferred that employed persons are generally more alert than unemployed persons about relative prices and quality, as well as better informed about the transactional processes. In this paper, we examine the significance of the employment status of the buyer as a determinant of under-invoicing. The buyer's employment status is defined as a binary dummy viable: if the buyer is employed it is assigned a value of $1 ; 0$ otherwise. Table 10 shows that the sub samples of buyers who are employed are associated with a smaller magnitude of under invoicing $(26 \%, p<0.01)$ relative to general public $(38 \%, p<0.01)$. There is a significant difference between under invoicing in transactions between those buyers who are employed, and those buyers not employed $(t$ value $=$ $13.12, p<0.01)$.

\subsection{Under-invoicing and sector development}

Sector economic development is thought to be a significant factor contributing to an upward secular tends in real estate prices. Infrastructure development and increasing residential construction both affect the dynamic equilibrium of the residential housing market (Hromada, 2015). However, these two factors may move residential prices in unpredictable ways; An improvement in infrastructure (e.g., roads, bridges, electrification, water control, etc.) can be expected, ceteris paribus, to shift the demand curve for residential housing to the right. Whereas an increase in residential construction, ceteris paribus, can be expected to shift the supply curve for housing to the right. The net effect on prices is indeterminate. In this study, we examine only the effects of sector development on the statistical incidence of under invoicing of properties in real estate market. Table 11 displays the effects of three phases of sector development on the incidence of under-invoicing. The table shows that the incidence of under invoicing in housing

Table 9. Association between the reputation of the housing authority and the incidence of under invoicing (source: author's calculation)

\begin{tabular}{|l|c|c|c|c|}
\hline \multicolumn{1}{|c|}{ Reputation of housing authority } & $N$ & Mean & Std. Deviation & Difference between groups (independent T-test ) \\
\hline Low reputation & 170 & $39.147^{\star *}$ & 11.642 & $t$ value $=240.326^{\star *}$ \\
\hline High reputation & 168 & $19.898^{\star *}$ & 11.176 & \\
\hline
\end{tabular}

Note: This table exhibits nexus reputation of housing authority and level of under invoicing of sample of 338 contracts of real estate. To test the significance, $t$-statistics is used. ${ }^{\star} p<0.05 ;{ }^{* *} p<0.01$ represent significance level at the 1 , and $5 \%$ respectively.

Table 10. Association between the Buyer's employment status and the incidence under invoicing (source: author's calculation)

\begin{tabular}{|l|c|c|c|c|}
\hline \multicolumn{1}{|c|}{ Buyer's employment status } & $N$ & Mean & Std. Deviation & Difference between groups (independent T-test ) \\
\hline General public & 80 & $38.288^{\star *}$ & 0.1318 & $t$ value $=13.127^{\star *}$ \\
\hline Employed person & 258 & $26.880^{\star \star}$ & 0.1441 & \\
\hline
\end{tabular}

Note: This table exhibits association between nexus buyer's employment status and statistical incidence of under invoicing of sample of 338 contracts of real estate. To test the significance, $t$-statistics is used. ${ }^{\star} p<0.05 ;{ }^{* *} p<0.01$ represent significance level at the 1 , and $5 \%$ respectively. 
Table 11. Association between Sector Development and the incidence of under-invoicing (source: author's calculation)

\begin{tabular}{|l|c|c|c|c|}
\hline \multicolumn{1}{|c|}{ Sector development } & $N$ & Mean & Std. Deviation & Difference between groups (ANOVA) \\
\hline Transition phase & 69 & $35.464^{\star *}$ & 15.171 & $F$ value $=114.58^{\star *}$ \\
\hline Developed sector & 215 & $26.898^{\star *}$ & 14.300 & \\
\hline Developing sector & 54 & $32.741^{\star *}$ & 14.527 & \\
\hline
\end{tabular}

Note: This table displays the statistical association between sector development and the incidence of under invoicing in a sample of sample 338 real estate contracts. To test the significance, $t$-statistics is used. ${ }^{*} p<0.05 ;{ }^{*} p<0.01$ represent significance level at the 1 , and $5 \%$ respectively.

Table 12. Association between real estate market sentiment and the incidence of under invoicing (source: author's calculation)

\begin{tabular}{|l|c|c|c|c|}
\hline \multicolumn{1}{|c|}{ Real estate market sentiment } & $N$ & Mean & Std. Deviation & Difference between groups (independent T-test ) \\
\hline Cold market & 97 & $25.474^{\star \star}$ & 14.780 & $t$ value $=10.587^{\star \star}$ \\
\hline Hot market & 241 & $31.232^{\star \star}$ & 14.693 & \\
\hline
\end{tabular}

Note: This table displays the association between market sentiments and the incidence of under invoicing of sample of 338 contracts of real estate. To test the significance, $t$-statistics is used. ${ }^{*} p<0.05 ;{ }^{* *} p<0.01$ represent significance level at the 1 , and $5 \%$ respectively.

sectors in the developing and in transition phases is significantly larger $(32 \%$ and $35 \%$ respectively, $p<0.01)$ as compared to developed housing authority $(26 \%, p<0.01)$. There is also a significant difference between the under invoicing in developing, in transition and developed housing authority $(F$ value $=114.58, p<0.01)$.

\subsection{Under invoicing and market sentiment}

Previous studies carried out in capital and financial markets suggest that market sentiment plays a vital role in causing price volatility (Badru \& Ahmad-Zaluki, 2018; Rathnayake et al., 2019). Generally, one can identify two sentiments i.e. an optimistic sentiment that will tend to push up the general level of prices (hot market) and a pessimistic view that will tend to depress the general level of prices (cold market).

In this paper, market sentiment is defined as a binary variable; it is assigned a value of 1 for a hot market and 0 for a cold market. If the number of property transactions is higher than the average volume, is assigned a 1, 0 otherwise. In this study, we test whether there is a systematic relationship between market sentiment and the incidence of under invoicing in real estate market. The statistical evidence displayed on Table 12 shows that in a hot the real estate market, under invoicing in properties is more significant than in a cold market $(t$ value $=10.58, p<0.01)$.

\subsection{Result of basic model with all $\mathrm{Z}$-variables}

Table 13 reports the result when all the $Z$-variables are included. These variables include: Stamp duty, withholding tax, capital gain tax, sector development, transfer fee, and market sentiment are the significant variables in the OLS model-I from the $Z$-variables. The coefficient of capital gain tax is significantly and positively associated with under invoicing $(\beta=2.005, p<0.01)$. This finding has policy implication: to wit, an increase in the capital gains tax, ceteris paribus, will tend to be associated with a greater incidence of under-invoicing. The coefficient of corruption level or black money in economy is also positively correlated with under invoicing $(\beta=0.476$, $p<0.01)$. Similarly, the coefficient of rate of risk-free investment is positively correlated with under invoicing $(\beta=0.589, p<0.05)$. This evidence suggests that under invoicing increases due to an increase in the risk-free return. The coefficient of buyer's employment status is significantly positive correlated with the level of under invoicing $(\beta=0.025, p<0.05)$.

This finding suggests that if the number of employed buyers increases, the statistical incidence of under invoicing will tend to increase. The reputation of the housing authority plays a significant role in level of under invoicing. The beta coefficient of reputation of housing authority is negatively correlated with under invoicing $(\beta=-0.058$, $p<0.01)$. That finding suggests that a high prestige housing authority is associated with less under invoicing in properties and assets of real estate market. The evidence also suggests that the widening gap is significantly associated with under-invoicing of real estate market. The coefficient of reputation of housing authority is negatively correlated with under invoicing $(\beta=0.231, p<0.01)$. This finding can be interpreted to mean that as the gap between the DC rates and transaction values of assets in real estate market increases, the incidence of under-invoicing will tend to increase.

\subsection{Result of extreme bounds analysis}

In an EBA analysis the buyer's employment status emerged as robust determinants of under invoicing in real estate market. Sensitivity analysis tests whether $X$ - and $Q$-variables are robust or fragile? Out of twelve, three $Z$-variables are selected in each regression - 126 combinations by using $n ! /(k !(n-k)$ ! in total, are tested. Under this technique, the variable shows VIF 10, confidence level 0.95, and CI 0.95 are only selected. Table 13 and EBA and LASSO present results of the sensitivity test. The results indicate that (a) capital value tax, (b) corruption level in market, (c) buyer's profession, (d) reputation of housing scheme 
Table 13. Least squares estimates of parameters (source: author's calculation)

\begin{tabular}{|c|c|c|c|c|}
\hline & Pre-OLS & EBA & LASSO & Post-OLS \\
\hline \multirow[t]{2}{*}{ Capital value tax } & 2.005 & 3.737 & 3.215 & 2.937 \\
\hline & $(2.82)^{\star *}$ & $(3.45)^{* *}$ & $(4.33)^{\star *}$ & $(3.21)^{* *}$ \\
\hline \multirow[t]{2}{*}{ Stamp duty } & -2.254 & & & \\
\hline & $(1.95)$ & & & \\
\hline \multirow[t]{2}{*}{ Corruption level } & 0.476 & 0.758 & 0.646 & 0.318 \\
\hline & $(2.22)^{\star}$ & $(4.27)^{\star *}$ & $(3.97)^{\star *}$ & $(3.62)^{\star *}$ \\
\hline \multirow[t]{2}{*}{ Withholding tax } & -0.122 & & & \\
\hline & $(0.21)$ & & & \\
\hline \multirow[t]{2}{*}{ Capital gain tax } & 0.068 & & & \\
\hline & $(0.30)$ & & & \\
\hline \multirow[t]{2}{*}{ Rate of risk-free return } & 0.589 & & & \\
\hline & $(1.97)^{\star}$ & & & \\
\hline \multirow[t]{2}{*}{ Buyer's profession } & 0.025 & 0.050 & 0.102 & 0.011 \\
\hline & $(2.45)^{\star}$ & $(2.93)^{\star *}$ & $(3.53)^{\star *}$ & $(2.98)^{\star *}$ \\
\hline \multirow[t]{2}{*}{ Housing scheme repute } & -0.058 & & & -0.034 \\
\hline & $(2.62)^{\star *}$ & & & $(3.45)^{\star *}$ \\
\hline \multirow[t]{2}{*}{ Sector development } & 0.001 & & & \\
\hline & $(0.18)$ & & & \\
\hline \multirow[t]{2}{*}{ Transfer fee } & -0.529 & & & \\
\hline & $(0.72)$ & & & \\
\hline \multirow[t]{2}{*}{ Widening gap } & 0.231 & & & 0.517 \\
\hline & $(4.06)^{\star *}$ & & & $(5.32)^{\star *}$ \\
\hline \multirow[t]{2}{*}{ Market sentiment } & -0.121 & & & \\
\hline & $(0.07)$ & & & \\
\hline \multirow[t]{2}{*}{ _cons } & 0.151 & 0.141 & 0.135 & 0.159 \\
\hline & $(2.31)^{\star}$ & $(3.57)^{\star \star}$ & $(2.56)^{\star \star}$ & $(2.32)^{\star}$ \\
\hline$R^{2}$ & 0.55 & 0.51 & 0.48 & 0.49 \\
\hline AIC & 32.131 & & & 12.231 \\
\hline SBIC & 32.231 & & & 12.215 \\
\hline HQIC & 32.215 & & & 11.415 \\
\hline$N$ & 338 & 338 & 338 & 338 \\
\hline
\end{tabular}

Note: This table exhibits determinants of under invoicing of sample of 338 contracts of real estate. In first OLS was applied to find out potential determinants of under invoicing in real estate sector of Pakistan. In second step, we applied extreme bounds analysis (EBA) to find out the robust determinant out of set of potential determinants. In EBA, total of 126 combinations of using $n ! /(k !(n-k)$ ! formula of 4 regressors (4 level combination of variables of interest) from the $Z(n \times 13)$ vector were used. Detail of model is VIF 10, confidence level 0.95., and CI 0.95. The table also depicts the comparison of estimation results between traditional methods derived from the OLS and EBA technique on 36th months of trading periods. AIC $=$ Akaike's Information Criterion, SBIC = Schwarz's Bayesian Information Criterion, HQIC = Hannan-Quinn Information Criterion, and EBA = Extreme Bounds Analysis. Traditional methods are specified on the basis of permutations (126 regressions) and the best combination is selected on the basis of their smaller values of AIC, SBIC, and HQIC. ${ }^{*} p<0.05 ;{ }^{*} p<0.01$ represent significance level at the $1 \%$, and $5 \%$ respectively.

and (e) widening gap are the robust variables in determining under invoicing while the rest of the variables are fragile in the analysis as indicated in equation.

To measure the sensitivity and the robustness of the factors affecting under-invoicing in real estate, we compare the results of EBA and LASSO technique with traditional methods which include the Akaike's information criterion (AIC), the Schwarz's Bayesian information criterion (SBIC) and the Hannan-Quinn information criterion (HQIC) as shown in Table 13 and Post-OLS. We select the lower values of information criteria and derive fewer variables. The application of the EBA and LASSO techniques find that the model specification is limited to capital value tax, corruption level in market, buyer's profession, reputation of housing scheme and widening gap. Alternatively, traditional techniques (e.g., AIC, SBIC and HQIC) recommend capital value tax, corruption level in market, buyer's profession, reputation of housing scheme and widening gap selected on the basis of lower value of information criteria. 


\section{Conclusions}

The objective of this study is to examine the magnitude of under-invoicing in the real estate market in Pakistan and identify the factors that cause it. Our statistical sample consisted of 338 real property sale agreements. Our findings support (a) tax evasion hypothesis, (b) widening gap hypothesis, (c) corruption hypothesis and (d) signaling hypothesis. In Pakistan, there are various categories of tax in real estate properties e.g., Capital Gains Tax (CGT), Capital Value Tax (CVT), Stamp Duty and Withholding Tax or Advance Tax. In summary, the aggregate level of real state tax liability is almost $15-25 \%$ of recorded value that are levied in real estate market. Withholding tax is to be paid by the buyer and Capital Gains Tax is to be paid by the seller. We find that higher rates of taxation in the real estate market are strongly positively correlated with under-invoicing in that market. When executing a transaction real property, have a strong incentive to record an undervaluation of the transaction price in order to avoid the tax. A consequence of this kind of tax-avoidance behavior implies that as real estate tax rates increase, the statistical incidence of under invoicing in the real estate market increases.

A second finding of this study is that increases in corruption in the real estate market in Pakistan are systematically associated with higher levels of under invoicing in the market. In Pakistan, the documented rate of corruption and black money increases by $5 \%$ to $10 \%$ every year. Under invoicing is used to conceal the magnitude of corruption. A major finding in this paper is that there is a large gap between "deputy commissioner (DC) rates" and market prices of the counterpart properties. This gap encourages the circulation of undocumented funds in the market. The immediate consequence of the undocumented funds is manifested as tax evasion.

Many housing markets in Pakistan are located in high prestige housing society regions e.g., house prices of Defense Housing Authority (DHA) and Bahria Town are experiencing rising prices. However, housing prices of low prestige housing societies operating in the same geographic region may experience falling prices. Desirable areas located in low prestige housing societies can resist market trends because the demand curve is shifting to the right and the supply of good quality housing is inelastic in the short run. After reforms in the real estate market enacted the incumbent governmental authorities, the term "real estate" has become almost synonymous with the word "investment." The majority of the investors are allocating their savings to the real estate sector, which leads to a higher demand for housing. As a result, prices of residential as well as commercial properties are rising rapidly in Pakistan. That upward trend in prices is manifested as an incentive for real estate investors to practice under-invoicing.

The findings of this study suggest that investors and residential owners of real estate must be mindful of the reforms imposed by the incumbent government. Those reforms are manifested as volatile taxes imposed on real estate and subsidies provided by the government to this sector. The empirical findings of this study may be of interest to regulatory bodies and housing societies. Our findings suggest how administrative authorities can improve the efficiency of transactions in the real estate market by addressing causes of under invoicing. Focused policies would help to mitigate the statistical incidence of under-invoicing of real estate properties and thereby meliorate (but probably not eliminate) tax evasion.

In this study we used only observable factors thought to have a statistically significant relation to the valuation of residential real estate in Pakistan. Building on these findings, we propose that future research may be addressed to external factor that might influence the incidence of under-invoicing of housing properties. Examples of such factors are the status of law enforcement in a region, financing provided for and by known terrorist organizations and transactions in undocumented real estate.

\section{References}

Abidin, N. Z., Yusof, N., \& Awang, H. (2012). A foresight into green housing industry in Malaysia. International Journal of Mechanical and Industrial Engineering, 6(7), 373-381.

Ahmed Qureshi, T., \& Mahmood, Z. (2016). The magnitude of trade misinvoicing and resulting revenue loss in Pakistan. The Lahore Journal of Economics, 21(2), 1-30. https://doi.org/10.35536/lje.2016.v21.i2.a1

Alim, K., \& Ramakrishnan, S. (2017). Initial public offerings (IPO) performance during hot and cold issue market in $\mathrm{Pa}-$ kistan. SSRN Electronic Journal, 1-23. https://doi.org/10.2139/ssrn.2912413

Andrew, M., \& Meen, G. (2003). House price appreciation, transactions and structural change in the British housing market: a macroeconomic perspective. Real Estate Economics, 31(1), 99-116. https://doi.org/10.1111/j.1080-8620.2003.00059.x

Anson, J., Cadot, O., \& Olarreaga, M. (2015). Tariff evasion and customs corruption: does pre-shipment inspection help? The B.E. Journal of Economic Analysis \& Policy, 5(1), Article 33. https://doi.org/10.1515/1538-0645.1600

Arora, N., \& Singh, B. (2019). Impact of auditor and underwriter reputation on underpricing of SME IPOs in India. Management and Labour Studies, 44(2), 193-208. https://doi.org/10.1177/0258042x19829285

Ascherl, C., \& Schaefers, W. (2018). REITs and REOCs and their initial stock market performance: a European perspective. Journal of European Real Estate Research, 11(1), 4-27. https://doi.org/10.1108/JERER-10-2016-0036

Badru, B. O., \& Ahmad-Zaluki, N. A. (2018). Explaining IPO initial returns in Malaysia: ex ante uncertainty vs signaling. Asian Review of Accounting, 26(1), 84-106. https://doi.org/10.1108/ARA-11-2016-0133

Beja, E. L. (2008). Estimating trade mis-invoicing from China: 2000-2005. China and World Economy, 16(2), 82-92. https://doi.org/10.1111/j.1749-124X.2008.00108.x

Bian, X., Brastow, R., Waller, B., \& Wentland, S. (2019). Foreclosure externalities and home liquidity. Real Estate Economics, 47(4), 1-41. https://doi.org/10.1111/1540-6229.12301

Blackburn, K., Bose, N., \& Capasso, S. (2012). Tax evasion, the underground economy and financial development. Journal of Economic Behavior and Organization, 83(2), 243-253. https://doi.org/10.1016/j.jebo.2012.05.019 
Brobert, G. (2016). The global REIT market: initial-day performance of IPOs. Journal of European Real Estate Research, 9(3), 231-249. https://doi.org/10.1108/JERER-03-2016-0015

Brounen, D., Marcato, G., \& Silvestri, E. (2019). Price signaling and return chasing: international evidence from maturing REIT markets. Real Estate Economics, 47(1), 314-357. https://doi.org/10.1111/1540-6229.12247

Cassara, J. A. (2016). Trade-based money laundering: the next frontier in international money laundering enforcement. Wiley. https://doi.org/10.1002/9781119125389

Chen, C., Shi, H., \& Xu, H. (2013). Underwriter reputation, issuer ownership, and pre-IPO earnings management: evidence from China. Financial Management, 42(3), 647-677. https://doi.org/10.1111/fima.12006

Cheng, P., \& McMillan, D. (2015). Do initial reserves signal longterm IPO stock performance? Cogent Economics \& Finance, 3(1), 1018697. https://doi.org/10.1080/23322039.2015.1018697

Choudhry, R. M., Gabriel, H. F., Khan, M. K., \& Azhar, S. (2017). Causes of discrepancies between design and construction in the Pakistan construction industry. Journal of Construction in Developing Countries, 22(2), 1-18.

https://doi.org/10.21315/jcdc2017.22.2.1

Cooley, T. F., \& LeRoy, S. F. (1981). Identification and estimation of money demand. American Economic Review, 71(5), 825-844.

Gulzar, A., Junaid, N., \& Haider, A. (2010). What is hidden, in the hidden economy of Pakistan? Size, causes, issues, and implications. Pakistan Development Review, 49(4), 665-704. https://doi.org/10.30541/v49i4iipp.665-704

Haque, N. U. (2015). Flawed urban development policies in Pakistan. PIDE Working Papers, 1(119), 1-20.

Hasan, A. (2010). Migration, small towns and social transformations in Pakistan. Environment and Urbanization, 22(1), 33-50. https://doi.org/10.1177/0956247809356180

Hromada, E. (2015). Mapping of real estate prices using data mining techniques. Procedia Engineering, 123, 233-240. https://doi.org/10.1016/j.proeng.2015.10.083

Hui, E. C. M., \& Wang, Z. (2014). Market sentiment in private housing market. Habitat International, 44, 375-385. https://doi.org/10.1016/j.habitatint.2014.08.001

Hutchison, N., \& Disberry, A. (2015). Market forces or institutional factors: what hinders housing development on brownfield land? Journal of European Real Estate Research, 8(3), 285-304. https://doi.org/10.1108/JERER-07-2015-0029

Jeribi, A. (2015). Measuring underwriter reputation: evidence from the Tunisian stock market. Corporate Reputation eJournal, 2(1), 2014-2015. https://doi.org/10.2139/ssrn.2557543

JLL and LaSalle. (2020). Global Real Estate Transparency Index 2020 Rankings. https://www.jll.co.in/en/trends-and-insights/ research/global-real-estate-transparency-index/greti-globalrankings-and-methodology

Leamer, E. E. (1983). Let's take the con out of econometrics. American Economic Review, 73(1), 31-43.

Leamer, E. E. (1985). Sensitivity analyses would help. American Economic Review, 75(3), 308-313.

https://doi.org/10.1126/science.151.3712.867-a

Levine, R., \& Renelt, D. (1992). A sensitivity analysis of crosscountry growth regressions. American Economic Review, 82(4), 942-963.

Ling, D. C., Naranjo, A., \& Scheick, B. (2019). Asset location, timing ability and the cross-section of commercial real estate returns. Real Estate Economics, 47(1), 263-313.

https://doi.org/10.1111/1540-6229.12250
Liu, C. H., Liu, P., \& Zhang, Z. (2019). Real assets, liquidation value and choice of financing. Real Estate Economics, 47(2), 478-508. https://doi.org/10.1111/1540-6229.12148

Low, S. P., Gao, S., \& Teo, L. L. G. (2016). Gap analysis of green features in condominiums between potential homeowners and real estate agents: a pilot study in Singapore. Facilities, 34(11/12), 630-648. https://doi.org/10.1108/F-02-2014-0012

Moosa, I. A., \& Cardak, B. A. (2006). The determinants of foreign direct investment: an extreme bounds analysis. Journal of Multinational Financial Management, 16(2), 199-211. https://doi.org/10.1016/j.mulfin.2005.07.002

Musliu, A., Sopi, L., Wood, M., \& Hamidi, A. (2015). Under invoicing of imported broiler meat: a challenge to the development of the local broiler industry in Kosovo. Albanian Journal of Agricultural Sciences, 14(2), 121-126.

Newberry, R., \& Collins, M. (2017). Sales role play: an online simulation. Journal of Instructional Pedagogies, 19, 1-7.

Pakistan Bureau of Statistics. (2017a). 6th population and housing census. Pakistan Bureau of Statistics.

Pakistan Bureau of Statistics. (2017b). Population census 2017. https://www.pbs.gov.pk/content/population-census

Patnaik, I., Sen Gupta, A., \& Shah, A. (2012). Determinants of trade misinvoicing. Open Economies Review, 23, 891-910. https://doi.org/10.1007/s11079-011-9214-4

Pugh, C. (2001). The theory and practice of housing sector development for developing countries, 1950-99. Housing Studies, 16(4), 399-423. https://doi.org/10.1080/02673030120066527

Rathnayake, D. N., Louembé, P. A., Kassi, D. F., Sun, G., \& Ning, D. (2019). Are IPOs underpriced or overpriced? Evidence from an emerging market. Research in International Business and Finance, 50, 171-190. https://doi.org/10.1016/j.ribaf.2019.04.013

Rymarzak, M., \& Siemińska, E. (2012). Factors affecting the location of real estate. Journal of Corporate Real Estate, 14(4), 214-225. https://doi.org/10.1108/JCRE-11-2012-0027

Sandmo, A. (2005). The theory of tax evasion: a retrospective view. National Tax Journal, 58(4), 643-663. https://doi.org/10.17310/ntj.2005.4.02

Santosa, F., \& Symes, W. W. (1986). Linear inversion of bandlimited reflection seismograms. SIAM Journal on Scientific and Statistical Computing, 7(4), 1307-1330. https://doi.org/10.1137/0907087

State Bank of Pakistan. (n.d.). https://www.sbp.org.pk/ecodata/ index2.asp

The World Bank. (2019a). Ease of Doing Business Index. Retrieved April 22, 2020, from https://data.worldbank.org/indicator/IC.BUS.EASE.XQ

The World Bank. (2019b). Population in the largest city. Retrieved April 22, 2020, from https://data.worldbank.org/indicator/ EN.URB.LCTY.UR.ZS?view=chart

Tibshirani, R. (1996). Regression shrinkage and selection via the lasso. Journal of the Royal Statistical Society: Series B (Methodological), 58(1), 267-288. https://doi.org/10.1111/j.2517-6161.1996.tb02080.x

Tufail, S., \& Batool, S. (2013). An analysis of the relationship between inflation and gold prices: evidence from Pakistan. The Lahore Journal of Economics, 18(2), 1-35. https://doi.org/10.35536/lje.2013.v18.i2.a1

Transparency International. (n.d.). Corruption Perceptions Index. https://www.transparency.org/en/cpi/2020/index/nzl

Wahid, A., Khan, S. A., \& Mumtaz, M. Z. (2019). Pricing performance of cross-listed and local IPOs: evidence from alternative investment market. Business \& Economic Review, 11(3), 1-28. https://doi.org/10.22547/BER/11.3.1 
Waltl, S. R. (2019). Variation across price segments and locations: a comprehensive quantile regression analysis of the Sydney housing market. Real Estate Economics, 47(3), 723756. https://doi.org/10.1111/1540-6229.12177

Wang, Z., \& Hui, E. C. M. (2017). Fundamentals and market sentiment in housing market. Housing, Theory and Society, 34(1), 57-78.

https://doi.org/10.1080/14036096.2016.1196240
Woodward, L., \& Tan, L. M. (2015). Small business owners' attitudes toward GST compliance: a preliminary study. Australian Tax Forum, 3, 1-34. https://doi.org/10.2139/ssrn.2666317 World Economic Forum. (2019). Global competitiveness report. Retrieved April 22, 2020, from https://www.weforum.org/reports/the-global-competitiveness-report-2020

Zameen. (2019). Pakistan Real Estate Price Index. Retrieved April 22, 2020, from https://www.zameen.com/index/ 